DOI: http://doi.org/10.31617/k.knute.2019-03-19.21

\title{
ВПЛИВ ІНФОРМАЦІЙНОГО ШУМУ НА ПРИЙНЯТТЯ РІШЕННЯ
}

\author{
Бедюх А.В. \\ студентка 3 курсу \\ кафедра маркетингу \\ Гамова I. B. \\ к.е.н., доцент \\ кафедра журналістики та реклами \\ Київський національний торговельно-економічний університет, \\ Україна
}

Ключові слова: інформачія, інформачійний потік, інформачійний шум, класифікація, прийняття рішення, управління.

Keywords: information, information flow, information noise, classification, decision-making, management.

3 розвитком інформаційних технологій та появою значних потоків інформації, обов'язковим атрибутом останніх стає інформаційний шум. Вивченням даної проблеми свого часу займався американець К. Шеннон.

Ним була розроблена ціла теорія, присвячена процесу передачі інформації та виникненню стороннього ефекту - інформаційного шуму, який ускладнює весь процес передачі інформації і iї правильне сприйняття людиною.

Теоретичні та практичні аспекти інформаційного шуму досліджували такі науковці, як А. Арсул, В. Варенко, Ю. Ільїн, А. Миронов, А. Доронін, С. Сазонов, Д. Вишня, Р. Акопов та ін., однак досліджень стосовно впливу інформаційного шуму на прийняття рішення вкрай мало [1].

Загалом, в науковій літературі, інформаційний шум розглядають у двох аспектах. 3 однієї сторони, він $є$ випадковою перешкодою на шляху поширення сигналів, а 3 іншої - це непотрібне суб'єктові повідомлення, незалежно від того, відоме воно йому чи ні.

Найбільш повне та грунтовне визначення інформаційного шуму подане А.Д. Арсулом - це явище, коли через надходження значного обсягу інформації, більша іiі частина стає нерелевантною, тобто некорисним сигналом, а саме шумом, відфільтрувати який надзвичайно важко [1]. 
Таким чином, шум - це все те, що призводить до маскування корисного сигналу, в результаті чого інформація стає неповною, відбувається іiї спотворення, відповідно, знижується ії якість.

Аналіз наукових джерел 3 досліджуваної проблеми дозволяє зробити висновки про різноманітні погляди на класифікацію інформаційних шумів $[2 ; 3 ; 4]$. Підсумувавши їх, можемо виділити основні ознаки класифікації та види інформаційного шуму:

1. За структурою шуму виокремлюють: шум, що виникає внаслідок надлишку неважливої для реципієнта інформації; шум, що виникає внаслідок надлишку важливої та релевантної інформації, що неодноразово повторюється.

2. За ступенем навмисності шуму виділяють: шум, який джерело інформації генерує навмисно; ненавмисний шум.

3. За механізмом дії шуму: такий, що викликає емоції; такий, що містить надлишок інформації; такий, що містить мало корисної i надлишок непотрібної інформації; такий, що містить семантичну неоднозначність або плутанину.

4. За витоком шуму буває: шум, що виходить 3 джерела комунікації; шум, причиною якого є канал комунікації; шум, що пов'язаний $з$ інтерпретацією інформації і причиною якого є реципієнт.

5. За наслідками шуму: шум, що легко може бути відфільтрований i не призводить до затримки часу на інтерпретацію інформації; шум, що призводить до затримки часу на інтерпретацію інформації; шум, що призводить до неможливості декодування інформації.

6. За втратами від шуму: шум, що не призводить до фінансових втрат; шум, що призводить до незначних фінансових втрат; шум, що призводить до значних фінансових втрат; шум, що призводить до критичних фінансових втрат;

7. За частотою виникнення шуму: шум, що виникає зрідка; шум середньої повторюваності; постійний шум.

8. За важливістю комунікаційного каналу, в якому виникає інформаційний шум: шум у каналі комунікації низької важливості; шум у каналі комунікації середньої важливості; шум у важливому каналі комунікації.

Крім того, виділяють три типи інформаційних шумів: фізичні, семантичні та прагматичні. Фізичні шуми заважають поширенню сигналу, семантичні - заважають засвоєнню змісту повідомлення, а прагматичні шуми - це зрозуміла, але не потрібна частина повідомлення [4, с. 39].

Як відомо, інформацію використовують для того, щоб зробити висновок або прийняти рішення. Прийняття рішень $є$ найважливішою 
функцією управління, що становить основу управлінського процесу [5, c. 227].

Відзначимо, що управлінське рішення - вибір альтернативи, здійсненою керівником у рамках його посадових повноважень i компетенції й спрямованої на досягнення цілей організації. На наш погляд, вибір рішення є певним процесом, а саме рішення - результатом вибору із сукупності доступних альтернатив. Щоб ці рішення були правильними, інформація повинна бути достовірною, повною, актуальною, корисною, зрозумілою тощо.

Отже, всебічна обгрунтованість рішення означає насамперед необхідність прийняття його на базі максимально повної і достовірної інформації, проте інформаційний шум чинить у цьому перешкоди. Інформаційний шум впливає на прийняття управлінського рішення, адже відбувається спотворення інформаційного сигналу, що ускладнює весь процес передачі інформації і ії̈ правильне сприйняття іiї людиною.

Для боротьби 3 інформаційним шумом варто застосовувати фільтрацію даних - перевіряти належність фактичного значення складових повідомлення до множини припустимих значень або відповідності потребам користувача.

Таким чином, інформаційний шум призводить до неповноти, або спотворення отриманої інформації, знижуючи ії якість, тим самим заважаючи прийняттю ефективного управлінського рішення.

\section{Список використаних джерел}

1. Арсул А.Д. Информационный шум / А.Д. Арсул. - М. : Академический Проект, -2017.-281 с.

2. Варенко В.М. Інформаційно-аналітична діяльність : навч. посіб. / В. М. Варенко. - К. : Університет «Україна», 2014. - 417 с.

3. Горбаткова А. Ф. Проблема информационного шума в жизни человека XXI века / А.Ф. Горбатенкова, В.В. Котлярова// Научнометодический электронный журнал «Концепт». - 2017. - № 7. С. 6-59.

4. Медведєва В.Виникнення інформаційних шумів та шляхи їхнього усунення / В. Медведєва // Вісник Книжкової палати. - 2016. - № 7. C. $38-40$.

5. Шурпенкова Р.К.Прийняття управлінських рішень як важлива функція управління підприємством / Р.К.Шурпенкова // Глобалізаційні процеси в розвитку національних економік : тези матеріалів міжнародної науково-практичної конференції. - Тернопіль, 2016. - Ч. 2. - C. 226-228. 